\title{
The Use of Social Media as the New Platform for Women's Campaign in Local Executive Election
}

\author{
Mouliza K.D Sweinstani* \\ The Center for Political Studies-Indonesian Institute of Sciences, Indonesia
}

\begin{abstract}
The advancement of information and communication technology makes women regional head candidates have many choices to campaign themselves to the public. This study aims to analyze how the female candidate's digital campaign model in the Simultaneous Regional Election (Pilkada) in 2018 can influence public perceptions of female candidates. By using a mixed method approach through the content analysis method in 1881 female candidate social media uploads (twitter and Instagram) during the four months of the 2018 regional election campaign, it can be concluded that female candidates take advantage of gender stereotypes that have been attached to women while communicating with voters. This strategy can be seen from how female candidates carry the political issues promoted and how they attract the attention of voters by representing their gender identities (as a woman). However, there is no correlation between the use of social media and their winning. Social Media campaign at least can be a tool for women to reduce bias in the society through its feature to blow up their programs in a borderless society. This study also succeeded in elaborating Newman and Perloff's political marketing theory by adding electoral system indicators to "social imaginary" domains which in the type of plurality electoral system with a single district such as Pilkada, candidates tend to get closer to the whole community, rather than creating identity similarities to certain segment.
\end{abstract}

Keywords: Digital Campaign, Pilkada 2018, Social Media Campaign, Political Campaign, Female candidates 


\section{Introduction}

Changes in local government regulation and its head electoral mechanism in Indonesia indirectly have an impact on women's participation in becoming candidates for regional heads. Before the era of direct elections, women tended to face some difficulties to be elected as regional head. This was partly due to the "election by legislative" mechanism that were implemented and the gender ideology constructed by the government.

During the New Order, under Law No. 5 year 1974 concerning the Principles of Government in the Region, the mechanism of regional head elections was elected by the local legislative or DPRD with a strong intervention by the president (Soeharto). In addition, the construction of gender ideology at this time placed women as "the others" in politics. Consequently, this condition leads to the difficult for women to be elected (Sweinstani, 2018). In this era, there were only two female regional leaders, namely Tuty Hayati Anwar (Majalengka Regent from 1998-2003) and Molly Muyahati Djubaedi (Mayor of Sukabumi 1998-2003) (Dewi, 2015). Continued to the early reform era under Law No. 22 year 1999 concerning Regional Government, local leader election mechanism was still elected by the local legislative combined with the limited intervention from the central government. Unfortunately, female leaders were still limited. There were only five elected female regional heads. They were Rustriningsih (Kebumen Regent 2000-2005), Haeny Relawati Rini Widyastuti (Tuban Regent 2001-2006), Tuty Hayati Anwar (Majalengka Regent 2003-2008), Iriani (Karanganyar Regent 2003-2008), and Atut Chosiyah (Deputy governor of Banten 20012006) (Dewi, 2015).

In the era of direct local elections which started in 2005, changes in the mechanism of regional head elections did not necessarily increase the electability of regional head women. Nearly $79.4 \%$ of the elections that took place between 2005-2006 did not include female candidates (Women Research Institute, n.d). Meanwhile, in the 2015 Simultaneous Regional Election, there were only $7.47 \%$ of female candidates who qualified. In the 2017 simultaneous regional elections, women's participation declined to $7.17 \%$, or similar with only 48 women of 670 candidates for local leader candidates/vise local leader. From the total women competing in 2017 Local Election, only 13 of them were successfully elected. Whereas in 2018, 101 women consisting of 49 candidates for regional heads and 52 candidates for vise regional heads run for regional head elections held in 171 regions. Of these, six of them (five female deputy regional head candidates and one female regional head candidate) were declared not meeting the requirements (TMS) by the General Election Commission (KPU). Thus, in the 2018 Simultaneous Regional Election, there were 94 women or $9.18 \%$ of the total 1,030 candidates who were declared eligible (MS) would compete for the top executive chair at the local level (KPU RI, 2018).

Conceptually, direct election will give bigger chance to women to be nominated as candidates due to the competitive mechanism so that everyone met the qualification can join it. However, fluctuations in the number of female candidates for regional head throughout the direct election showed that women actually still faced several obstacles though the system has been changed. The situation of political competition that is still gender neutral and the absence of affirmative action in regional head election mechanism make this election is far from the spirit of affirmative action for women in politics (Mosse, 1993; Partini, 2014; Sweinstani \& Mariyah, 2017). Moreover, the condition of "the novelty of women in politics" makes women 
as the newcomer in politics who is labeled unqualified and unexperienced. This situation then sometimes leads to the negative stereotype of women's leadership.

Looking at the increase of female candidates in the 2018 regional election, it could not be said that women has reach significant achievement in becoming the regional head (candidates). It mainly because there is no guarantee that states that the more female candidates joining election, the more women regional head will be elected (Sweinstani, 2018). In other words, the phenomenon of women's participation in the direct local election shows that even though access for women to participate in regional head election has been opened, their electability is still low. ${ }^{1}$ Whereas, previous studies about the urgency of women in politics stated that when women lead, there will be a tendency that she will focus more on welfare, children, and women specific agenda (Schwindt-Bayer, 2005; Svaleryd, 2009; Swers, 2002). The obstacle for women candidate when running for office sometimes happened in their nomination and campaign stage. However, in the midst of this condition women also have their own creativity to deal with all the barriers by some strategies included utilized the advancement of information technology. Therefore, this study presents to be able to see the dynamics that must be faced by female candidates for regional heads, especially during the nomination period seen from the campaign strategies.

More specifically, this study focuses on how female candidates in the 2018 regional election get closer to voters through a digital campaign strategy. This study is important to do because of what happened during the campaign period can construct the public's perception of the candidate. Even in the case of women's electability, public perceptions of female candidates may not necessarily be a determining factor for women's electability.

Regarding the digital campaign strategy, this campaign method is interesting to be studied because currently, there are many politicians who use cyber media as a new platform in their efforts to get closer to voters. According to Andiana (2013), in politics, cyber/digital media is seen as a promising opportunity by politicians as a medium to communicate with audiences. The use of this media for political purposes began to climb after the implementation of the 2009 presidential election. The surge in the use of cyber media as a new platform for political campaigns made sense because nowadays internet has become an inherent part of Indonesian society.

Based on data obtained from the Association of Indonesian Internet Service Providers (APJII), the trend of internet users in Indonesia has increased every year. In 2017, the penetration of internet users in Indonesia reached $54.68 \%$ (143.26 million people). It means that more than half of Indonesian can access internet (APJII, 2017). Assuming that political actors have a tendency to use all media that are considered potentially and promisingly increase their popularity (Situmorang, 2012), It becomes reasonable if internet is also used in parallel way with other conventional media in political campaigns. National Survey Conducted by The Centre for Political Studies, Indonesian Institute of Sciences in 2018, also confirmed that cyber media can be a great opportunity to attract the attention of novice voters, especially young voters, because they are categorized as the most active cyber media user in accessing social media and political news through online media.

\footnotetext{
${ }^{1}$ According to the United Cities and Local Government (UCLG) quoted by Markham the global average of women in regional head positions in the world is only less than 5\% (Markham, 2013).
} 

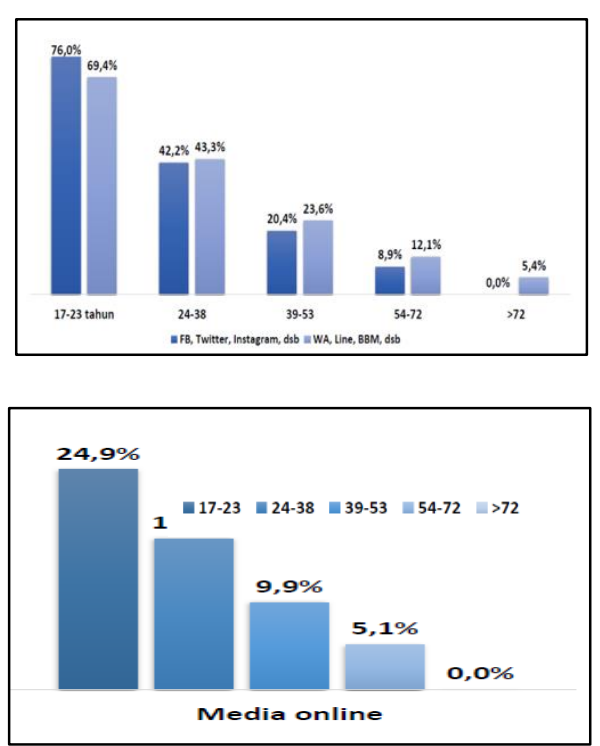

Source: 2018 LIPI Public Survey
Figure 1. The frequency of social media usage based on age group

Figure 2. Use of Online Media to access political news based on age

Some previous studies, especially those carried out in Western countries, show that online campaigns through websites allow for an interactive pattern of communication between candidates and their voters (Warnick, Xenos, Endres, \& Gastil, 2005) and political personalization that allows voters to become more familiar with their future leaders (Adam \& Maier, 2010). Furthermore, Gibson and McAllister (2006) explained that website campaign had a positive relationship with the candidates' votes. So is the online campaign using social media such as Twitter, Kruikemeier Sanne (2014) concluded that candidates who used Twitter in their campaigns were able to get a bigger vote than those who did not. Especially if this media is used by candidates as a means of building interactive relationships with voters, support for him will be greater than those who do not do the same.

When previous studies in the West focused on online campaigns through websites and Twitter, this study focused more on how female candidates use their Instagram and Twitter accounts in their digital campaign. The author chose Instagram because Instagram is now a social media that has a significant number of active users. Even though according to a survey conducted by Hootsuite and We Are Social at the beginning of 2018 said that Instagram was not the most active used social media (Hootsuite; We Are Social, 2018), in fact Instagram in Indonesia has become a social media platform with high user productivity. Based on the Instagram data release quoted by Tempo.co in July 2017, it is known that Instagram active users in Indonesia every month are around 700 million users. This number is higher than the number of active users at the beginning of 2016 which was only 22 million. Besides, based on data from Instagram, Indonesia is listed as the largest Instagram Story producing country in the world, by the double amount of content which is higher than the global average (Tempo.co, 2017).

With the intensity of such Instagram usage, political figures and political parties then do not want to miss using this media as a platform to bring them closer to voters. Moreover, according to Hootsuite, the advantage offered by Instagram is that this media can facilitate peer-to-peer sharing through Instagram stories and live video features. This feature is often 


\section{SOCIAL SCIENCES IN THE 21ST CENTURY}

used by public figures including politicians to communicate with the public without the need to meet face to face. Due to these reasons, the study of Instagram as a new media in political communication is necessary to see whether this media has succeeded in constructing people's perceptions (voters) of the candidates. Meanwhile, the selection of twitter as a social media observed was based on the reason that until now twitter is still a medium that is often used by politicians to build a public image of themselves. In addition, Twitter also has the potential to be able to build interactive relationships between candidates and the community through the twit pattern offered.

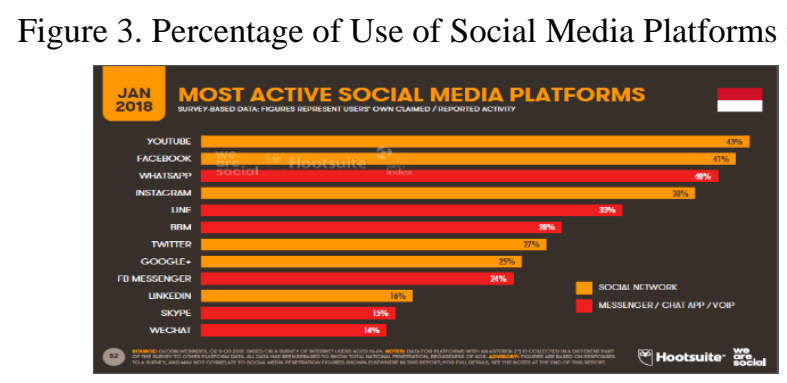

Source: (Hootsuite; We Are Social, 2018)

The aspects seen from the utilization of these two social media are the content that is published and the way of female candidates communicate as well as deliver their political message to the voters. Previous studies conducted by Hayes and Lawless (2016, pp. 7-9) concluded that in the polarized era of US politics and in the era that women are no longer considered as new actors in politics, there was no reason for male and female candidates to campaign differently seen from the issue appointed, language style, and personal characteristics conveyed to the voters. In the past, women could benefit from raising issues and using a style of speech that emphasized the feminine side or gender stereotypes that had long been attached to women. For example, by raising women's specific issues, showing the side that she is a new actor (woman) in politics, and showing a feminine appearance as her "female" identity. However, these trends change over time, where both male and female candidates currently emphasize efforts to convince voters that they are adept at handling various issues and deserve to be elected. Through this study, the authors will test whether the results of the Hayes and Lawless studies apply in the context of the elections in Indonesia or even produce different findings.

The analysis of digital campaigns will be associated to the voter behaviour towards female candidates for regional head candidates as what female candidates do through campaigns on social media can influence perceptions and voting behaviour of voters. The locus of this study is the four regions that hold the Governor's Election in 2018 which have female candidates both as candidates for Governor and candidate for Deputy Governor. The four regions are East Java, Central Java, Lampung and West Kalimantan. In the four regions, the authors conducted an analysis of 5 female candidates, 2 Governor Candidates in East Java and West Kalimantan, and 3 candidates for Deputy Governor in East Java, Central Java, and Lampung. In order to find out more about digital campaigns done regional head female candidates, the authors proposed the following research questions:

1. How do female regional head candidates use social media in their campaigns, especially in terms of the content of the message and how to deliver the message? 
2. How do these two political marketing media influence public perceptions of female candidates?

\section{Methods}

In this study I used mixed method approach and conduct content analysis on uploads from candidate's social media accounts. Even though objectively research with this method processes data by coding and calculating data, the mechanism of causality of each data processed using certain narratives that are the domain of qualitative approaches also needs to be done (Krippendorff, 2004, pp. 17). The addition of qualitative methods to support the analysis of the study is due to the weakness of the (quantitative) content analysis method which cannot explain the connotation of a phenomenon/fact. Related to this research, I used

Qualitative methods to provide a more in-depth explanation of the meaning of their social media uploads.

The time limit for observing digital campaigns on Twitter and Instagram accounts of the five research subjects was ones which were uploaded in March to the last day of the campaign period, June 23, 2018, with a total of 1881 uploads. Meanwhile, to found out how the public perception of female candidates in this digital era, the authors used survey data from several survey institution or previous research conducted in Lampung Province, Central Java Province, East Java Province, and West Kalimantan Province.

The aspects observed from the candidate's digital campaign were the content which uploaded by each candidate's social media whether it is directed at merely personification efforts or promoting the program and vision-mission; and the way they communicate to the voters. Regarding to the way of political communication, I cited the method proposed by Hayes and Lawless (2016, pp. 17-35) which looked at how female candidates use gender stereotypes in the political issues they carry and how they attract public's attention, whether by reflecting on gender stereotypes that have been attached to women or even refracting those stereotypes. Both of these was seen from the intensity of interactivity consisting of twit/post, mention (@), hashtag (\#) or repost / retweet (RT / Repost), and types of female candidate uploaded content in both social medias. Regarding to the type of uploaded content, I divided the analysis unit into two main aspects, the personal content related to personal life, family, and female candidate professions and political socialization content consisting of political campaigns, political activities and political statements and attitudes others that can support political campaigns (political standpoints). The entire data was processed by using Excel application which will eventually be presented in the form of tables and graphs. The choice of data processing method was based on time limitations, hardware, and software so that it is not possible for writers to conduct a computational content analysis. The list of media to be observed is:

Table 1. List of social media and online media observed

\begin{tabular}{|c|c|c|c|c|}
\hline No & Name & Nominate As & Twitter & Instagram \\
\hline 1 & $\begin{array}{ll}\text { Khofifah } & \text { Indar } \\
\text { Parawangsa } & \end{array}$ & $\begin{array}{l}\text { Prospective Governor Jawa } \\
\text { Timur }\end{array}$ & @ KhofifahIP & @khofifah.ip \\
\hline 2 & $\begin{array}{ll}\text { dr. } & \text { Karolin } \\
\text { Natasa } & \text { Margret } \\
\end{array}$ & $\begin{array}{l}\text { Prospective } \quad \text { Governor } \\
\text { Kalimantan Barat }\end{array}$ & @ dr_karolin & @ dr_karolin \\
\hline 3 & Dra. Ida Fauziyah & $\begin{array}{l}\text { Prospective } \quad \text { Deputy } \\
\text { Governor Jawa Tengah }\end{array}$ & @idafauziyah & @idafauziyahnu \\
\hline 4 & $\begin{array}{l}\text { Hj. Chusnunia, M.Si., } \\
\text { M.KN., PhD }\end{array}$ & $\begin{array}{ll}\text { Prospective } & \text { Deputy } \\
\text { Governor Lampung } & \end{array}$ & @ noenia & @nuuunik_ \\
\hline 5 & Puti Guntur Soekarno & $\begin{array}{l}\text { Prospective Deputy } \\
\text { Governor Jawa Timur }\end{array}$ & @puti_soekarno & @puti_Soekarno \\
\hline
\end{tabular}




\section{Result and Discussion}

\subsection{Political Marketing Domain in Influencing Public Perception: A Theoretical Framework}

In conducting this study, the first theory that the author uses is Political Marketing theory, especially those proposed by Newman and Perloff. Political marketing is defined as the application of marketing principles and procedures in election campaigns carried out by individuals and organizations (parties) (Newman, 1999). Further explained by Newman and

Perlof (2004), political marketing is an exchange process where in this case politicians or the government provide an offer to the community (can be a program) so that the community wants to be in their camp.

If it is contextualized to the elections, the things offered by candidates can be in the form of programs, vision missions or leadership styles. By doing so, the candidates may get votes that can lead him to win the election. Newman and Perloff stressed that basically, voters are consumers of what candidates offer. A predictive model of voter behavior (Newman, 1999c) proposes a number of cognitive beliefs that may come from a wide range of sources, including the voter, word-of-mouth communication, the mass media, and the way the candidates "promote" him/herself. The model incorporates the influence of individuals" affiliation with groups of people in their social environment (Lazarsfeld, Berelson, \& Gaudet, 1944) and the influence of party affiliation and past voting behavior (Campbell, Converse, Miller, \& Stokes, 1960). Therefore, Newman and Perloff formulate five domains in political marketing that can influence voter perceptions /behaviour to a candidate, these five things are:

1. Political Issues, which reflects programs, visions, and missions or issues that carried by the candidates;

2. Social Imaginary, represents the use of stereotypes to appeal to voters by making associations between the candidate and selected segments in society. This component captures the influence of the role of party affiliation and other important social networks that shape voter behavior

3. Candidate Personality, captures the importance of a candidate's personality in helping to reinforce and manufacture an image in the voter's mind. It is related to how the candidate's personality can reflect the candidate's own image in public perspective,

4. Situational contingency, representing the dimensions of voter thinking that can be influenced by "hypothetical events" profiled during the campaign. This strategy is often used as a means of creating the illusion that one candidate is better at handling certain situations than the other candidates so that the voter ultimately chooses the candidate in question and considers the candidate the most deserving choice,

5. Epistemic Value represents an interesting dimension to the curiosity or novelty of voters in choosing candidates. With this dimension, it means that there are new things that can be presented by the candidate so that the voters are eligible to choose him/her.

By using this theory, I will see how the five dimensions were applied by the five female candidates of this study in their digital campaign that became part of the women's political marketing. However, the author also does not rule out the possibility of an analysis of other domains outside of the five domains by some finding during the research or elaboration of each 
domain proposed by Newman and Perloff. I consider this potential as this study will focus on female candidates at the local level in new democracies like Indonesia. Moreover, this theory has not been able to capture the borderless scope of digital campaign rather than the conventional one. Thus, this study is expected to be able to refine the theories constructed by Newman and Perloff which portray the political marketing phenomena in western countries.

After conducting an analysis by looking at the domain of political marketing of female governor and deputy governor candidates in the 2018 regional election, the authors then analyzed how it affected voter's behavior. In doing so, the three main approaches of voting behaviour is used. Generally, there are three approaches of voting behavior, namely: 1) Sociological Approach, which states that social class, religion, subculture and ethnic origin are the factors that determine voting behaviour 2) Psychological approaches focus on party

Identification, and candidate orientation issues and 3) Rational Approach, focuses on consideration of the costs and benefits that voters get when choosing one candidate (Attunes, 2010).

Related to the digital campaign done by female candidates, the three approaches above can be influenced by the way they deliver their political message through their post in social media. Regarding to marketing politics domain, a sociological approach can be caused by a political campaign containing 1) the domain of political issues, especially if the issues raised relate to identity issues; 2) social imagination by candidates to identify themselves with voter identity; and 3) a description of the candidate's personality which influences the voters to elect candidates on the basis of consideration. While the psychological approach can also be influenced by the domain of social imagination, especially if the candidate states that he/she is a part of particular party politics in accordance with the party of choice of the people. The last but not least, in the rational choice approach, voter literacy which forms the basis of voters' decision can be constructed if the candidate is able to lead relevant political issues to improve community conditions, situational contingency, and epistemic values about the novelty of the candidate.

\subsection{Digital Campaign Model by Candidates for Regional Heads}

Observations made by the author on 971 twitter uploads and 910 Instagram uploads of five female candidates in the 2018 regional election showed that in addition to campaigning through conventional media, female candidates also used social media as a medium to socialize the programs promoted to voters. In accordance with the results of the observation, female candidates for governor and deputy governor were known to place more emphasis on uploads aimed at the interests of political socialization by sharing various uploads of campaign activities, certain political statements and attitudes, and explicitly some of the programs carried out. Even though there were some uploads that were personal and out of political campaign activities-such as uploads relating to the family life of female candidates, appreciation to female candidate colleagues, and personal / family trips of female candidates-it took in small portion.

On the official Twitter account of them, there were only about $12 \%$ of the content that was personally charged. Meanwhile, on Instagram media, the personal content was uploaded less than the personal content uploaded in Twitter. Most of the content on Instagram is used to publish their political activities. This is possible because Instagram is a medium which is designed to share documentation of activities carried out both in the form of photos and videos. Thus, it became logic when most uploads on the Instagram account of each female candidate were about political campaign activities, posters of herself and political partners and bearer 


\section{SOCIAL SCIENCES IN THE 21ST CENTURY}

parties, as well as descriptions of programs arranged in interesting infographic forms. Therefore, it can be concluded that this study confirms the results of a study conducted by Hayes and Lawless previously which suggested that the current trend of social media upload content for female candidates during the company period was focused on publicizing the political socialization activities seen from the efforts of female candidates to promote the programs they offered.

Figure 4. Comparison of Twitter content for female candidates for 2018 regional elections

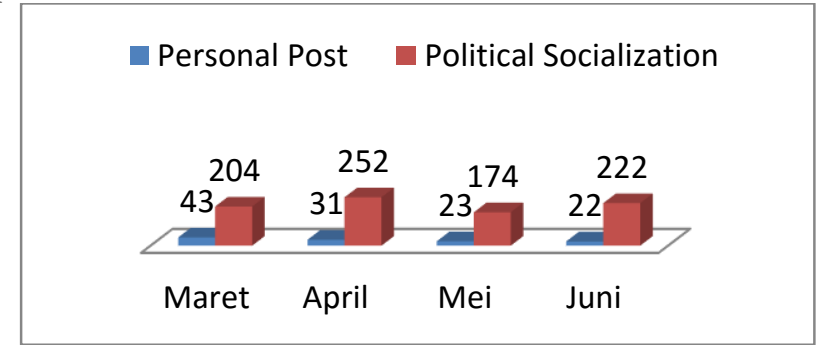

Source: Processed by the author based on Twitter observations March-23 June 201

Figure 5. Comparison of Proportions of Types of Personal Content and Content of Political Socialization

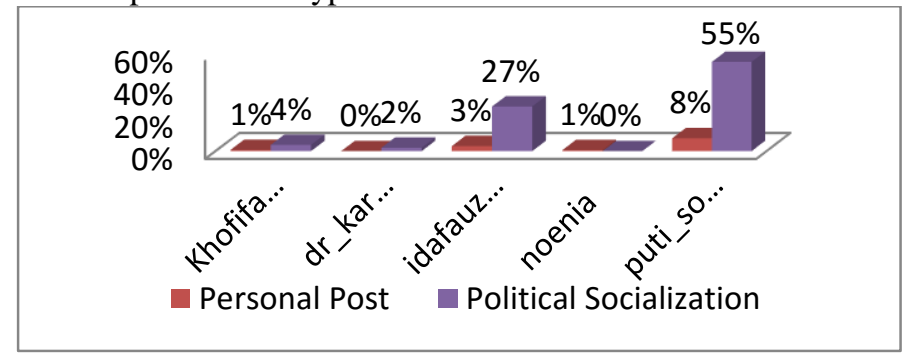

Source: Processed by the author based on Twitter observations March-23 June 2018

Regarding the content of political socialization, I divided the content of political socialization into three main aspects, namely political campaigns in accordance with Electoral Commission Provisions, political activities, and political standpoints that can reflect the political attitudes of female candidates, one of which can be seen from their political statements. Based on the results of the observation, it was known that the content of political activities that could be traced from a variety of documentation of visit/campaign/ public debate activities, was the most uploaded content in term of political socialization content. This strategy may be preferred by female candidates because they prefer to implied political campaigns which reflect the sense of closeness with the people rather than using high politics narration.

The second most uploaded content in term of political socialization content was about political standpoints or opinions, attitudes, and political ideas of female candidates. This type of content can be traced from some responses from of female candidates related to certain moments; such as their opinions on women's leadership and women's rights conveyed on women's day and Kartini's day, women's candidate attitudes to Indonesian diversity, and other matters of public concern. This type of content upload also increased sharply, especially in May (see picture 5) because at that time almost all female candidates expressed their attitudes and opinions about suicide bombings in Surabaya city. Apart from giving sympathy and empathy, they also delivered their respective analyzes of suicide bombings which involved a woman as the executant.

In spite of the documentation of their political activities, approaching to the Election Day the upload content of political socialization on female candidates showed a different trend. 


\section{SOCIAL SCIENCES IN THE 21ST CENTURY}

In June 2018, the uploaded content of political socialization was prioritized for conducting political campaigns that explicitly showed the campaign elements determined by the Electoral Commission Provision, namely the Name of the Candidate Pair, Sequence Number, Carrier Party, and Programs carried out. I analyze this trend change as a form of strategy for female candidates to be able to psychologically influence voters to vote. The assumption is that the more often the voters are shown the picture and the serial number of candidates, the easier it will be for voters to vote for them.

Figure 6. The proportion of Content for Political Socialization of Female Candidates for Regional Head

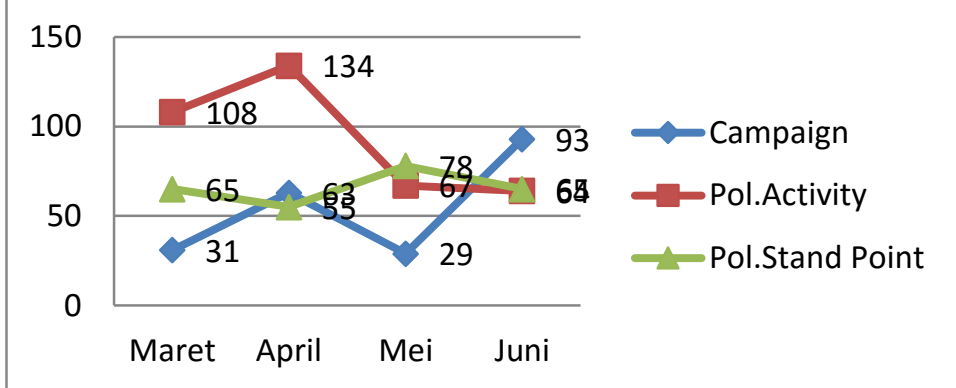

Source: Processed by the author based on Twitter observations March-23 June 2018

Meanwhile, related to the way female candidates' campaign, this study found that there were differences in the way of political communication was carried out by female candidates and male candidates. Judging from the political issues and programs carried out, both female and male candidates have programs for the benefit of women, in addition to programs for infrastructure, economic development, community welfare, and other issues relevant to their respective regions. The Ganjar-Yasin (Central Java) couple, for example, in addition to having a program for the economic well-being of the people of Central Java, the couple also had a program that is specific to women even in a smaller proportion than the Sudirman-Ida Fauziyah (the contender) couple. However, in the way of promoting the program about women, the political communication method used by Ida Fauziyah was more direct to the reasons and solutions offered from the specific issues of women promoted. This could be seen from the documentation of the visit to PT Sritex which was uploaded by Ida Fauziah. In the upload, Ida blended and gave appreciation to female factory workers as Indonesian warriors through written description. Delivering a more straightforward program about women is also delivered by Karolin Natasa which can be seen in the upload that reads "Anak dan perempuan adalah fokus saya dalam membangun Kalbar, karena saya perempuan, saya ibu, jadi paham kebutuhan anak dan perempuan (Children and women are my focus in developing West Kalimantan, because I am a woman, I am a mother, so I understand the needs of children and women $)^{2}$ ".

The other differences also could be seen from how female candidates attract the attention of voters. If Hayes and Lawless' study concluded that the language of female candidates tended not to reflect or bias the "female" identity inherent in them, this study actually found different facts. Some of the female candidates in this study actually used methods that reflected their "female" identity to attract the attention of voters. For example what was done by Chusnunia with the tagline "Click on the Veil". The tagline shows that Chusnunia is trying to use the symbol of women's identity to attract the attention of voters so

\footnotetext{
${ }^{2}$ Cited from Twitter and Instagram dr_karolin on March, 62018
} 
that voters recognize that she is a prospective female leader. Similarly, what was done by Khofifah who identified herself as "Kartini Jawa Timur". Kartini is one of respected women hero in Indonesia due to her dedication in fighting for women's emancipation. So, by engaged herself as Kartini from East Java, it can conclude that she tried to label herself as women hero for East Javanese. Besides, she also used the hashtag "\#budekhofifah", in which Bude in Javanese literally means father/mother's sister. The use of female salutation was also carried out by Puti Soekarno with the hashtag \#Mbakputi in which mbak means older sister.

This way of communication which more reflects the identity of women is possible because women are still consider as new actors in Indonesian politics. Struggle to increase

Women's representation in politics, especially in legislative branch, was begun in 2004. Whereas in the context of women regional heads, there was no specific affirmation policy to increase opportunities for women to lead the region. Therefore, with the wide and massive scoop of digital media, female candidates tend to use this platform to introduce themselves to public by stressing that they are the new alternative to local leadership that comes from women. Moreover, on special days for women such as international women's day and Kartini day, this difference is increasingly apparent because these female candidates are increasingly trying to show that they are women leaders who represent and pay attention to women's interests.

Unfortunately, based on several models of digital campaigns, female candidates had not fully used this media as a means of two-way communication or interactive communication with the voters. It could be seen from the type of interactivities on the Twitter account which were still dominated by tweets. Interactivity in the form of mention (@) that allows users to respond conversations with other users (community) is still limited in used. There were only 42 mentions (@) in total by female candidates for regional head during the observation. This interactivity model is in line with Andriana's findings in 2013 which stated that the digital campaign of President Soesilo Bambang Yudhoyono through his Facebook account was still passive.

Figure 7. Types of Twitter Interactivity Candidates for Regional Heads of Women

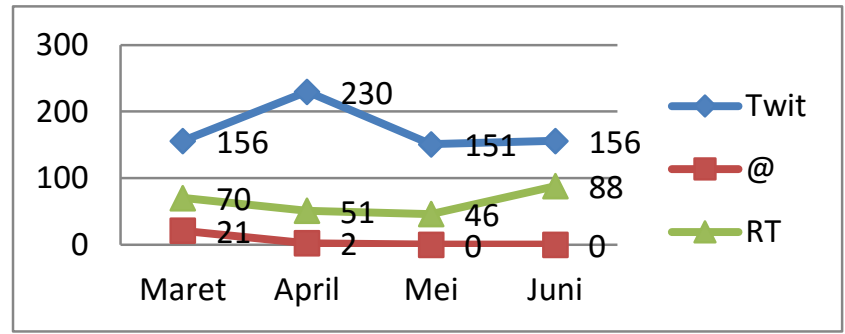

Source: Processed by the author based on Twitter observations March-23 June 2018

\subsection{Women's digital campaign in marketing politics domain}

If viewed from the domain of political marketing presented by Perloff and Newman, almost all five candidates had been able to run most of these domains in digital campaigns. With regard to the political issues' domain, issues that were led by female candidates were more likely to be related to the programs they appoint, including superior programs for the interests of women in their regions. They carried out the issue through social media both in the form of campaigns that directly stated the various programs in question, as well as through several activities that implied their attention to an issue which she finally adopted it as her flagship program. For example, in the campaign carried out by Khofifah Indar Parawangsa, Candidate for East Java Governor 2018, which deals with programs to improve the welfare and economic conditions of the people in the tourism sector, she did not directly campaign for 
various programs related to it. However, she prefers to do a description of the beauty of the tourist attraction of Bromo Tengger Semeru National Park (TNBTS) in its upload. After describing the desirability of the tourism object, she then developed a discussion with his followers on social media about the TNBTS participation program as one of the strategic national projects which is one of the programs in the Nawa Bhakti Satya program, a term for the vision and mission of the Khofifah-Emil couple.

Furthermore, related to the candidate personality domain, the five female regional head candidates in this research had also been able to build the domain in their digital political marketing efforts. This domain can be seen from various activities shared by these female candidates, not only those that are directly related to campaign activities but also those related to her personal life. Even though personal content has a small proportion, but in the era of

Social media where people can find out the other side a public figure, personal content can help candidates build images of their daily lives. Moreover, on Instagram which has live video feature, efforts to build a personal image in front of the public seems to be easier.

The next domain that female candidates have also shown in this research is the situational contingency domain which creates the illusion that they are better than other candidates. This could be traced from a number of uploads that showed criticism of female candidates in the current regional government policies and programs of other candidates, including the incumbent. One model of situational contingency that is clearly constructed by them can be seen from the candidate debate material that they often shared. By criticizing current programs and programs offered by other candidates, it reflects the efforts of female candidates who try to offer themselves as potential leaders who are better than others.

Meanwhile, related to the epistemic value domain, there are two perspective that can support this domain. Firstly, they offer their own newness among all candidates in that regional because the entire female candidate for this regional head is not an incumbent. Secondly, related to her identity as a woman. As explained in the previous section, almost all female candidates in this research used women identity in their communication to the voters. By showing some specific symbol of women, it can be concluded that they tried to construct new identity of a regional head leader which is the identity of women.

Finally, regarding to social imaginary domains that are related their social image which is related to their segment's identity, almost all female candidates in this research do not develop such social images. This can be seen from the absence of certain identity issues which were raised as their political issues. This phenomenon can be analyzed from the perspective of the electoral system used in regional head elections. The electoral system used in regional head elections is the First Past the Post (FPTP) system which is part of a plurality of forms with a single district. In this system, the candidates who win the election are those who get the majority vote, even if they do not have to be in absolute majoritarian. In other words, the candidate who will win the election is the candidate who gets the most votes (winner takes all)) (Reynolds, Reilly, \& Ellis, 2008). Therefore, candidates in the FPTP system tend to maximize all available resources to be able to persuade all voters in their region. Therefore, they do not target certain people as their voters. Implementation of this domain will certainly be different if the electoral system used is a proportional system with many districts. If the electoral system is the proportional on likewise in the legislative elections, the candidate can establish similarity of identity with a certain voter (market) so that his/her voice can be segmented in certain voter groups. 


\section{SOCIAL SCIENCES IN THE 21ST CENTURY}

Table 2. Forms of Political Marketing Domain Applications by Female Candidates

\begin{tabular}{|c|l|l|}
\hline No & \multicolumn{1}{|c|}{ Domain Political Marketing } & \multicolumn{1}{|c|}{ Application } \\
\hline 1 & Political Issue & $\begin{array}{l}\text { Shown in the form of socialization of programs promoted by } \\
\text { female candidates either by explicit campaigning or implicit / } \\
\text { implied through uploads of political activities or statements }\end{array}$ \\
\hline 2 & Social Imaginary & $\begin{array}{l}\text { Not done because it does not target a particular voter segment } \\
\text { but decays the community in the Province to obtain a majority } \\
\text { vote }\end{array}$ \\
\hline 3 & Candidate Personality & $\begin{array}{l}\text { Shown from various upload activities both political activities and } \\
\text { personal activities }\end{array}$ \\
\hline 4 & $\begin{array}{l}\text { Situational Contingency (Illusion } \\
\text { of Excellence) }\end{array}$ & $\begin{array}{l}\text { Shown from various uploads containing criticism of the ongoing } \\
\text { government or other candidates }\end{array}$ \\
\hline 5 & Epistemic Value (Novelty Illusion) & $\begin{array}{l}\text { It was shown by the publication that he was not an incumbent } \\
\text { and was a female leader where women could be other choices for } \\
\text { the head of the local area. }\end{array}$ \\
\hline
\end{tabular}

Source: Processed based on the analysis of the author

\subsection{Implication to Public Perception of Women's Leadership}

After conducting analysis of the digital campaign model carried out by female candidates in the Simultaneous Local Election in 2018, in this part I will analyze how the implication of its used to public perception of women running for office in local level. In general, almost in all countries, public assumes that politics is more difficult for women than other fields - even industries that recently been the subject of headline-grabbing allegations of sexism. Consequently, in the public's mind, politics is in hospitable to women (Hayes \& Lawless, 2016; Partini, 2014).

In Indonesia, some surveys conducted by some institutions such as Indonesian Survey Institute (LSI), IFES and Women Research Institute (WRI), indicated that public in Indonesia basically give the same opportunities for women and man in running for office (Ihsannudin, 2014; Women Research Institute, 2014; LSI, 2019). In 2014, WRI's survey showed that $62 \%$ of Indonesian agreed that women have the same capacity as men in running the government. Even $8 \%$ of them stated very agreed if women capacity in political leadership is same as men (Women Research Institute, 2014). The latest survey conducted by LSI in collaboration with of some Indonesian Researchers/Scholars and Australian National University in 2019 also concluded the same finding. Our survey showed that nearly $72 \%$ of 1.200 respondents confess that there is no difference between male and female capacities in running the office.

Figure 8. People's views on giving the same opportunity for women and men to run the government (left) and People views on the same leading capacity of women and men (right)
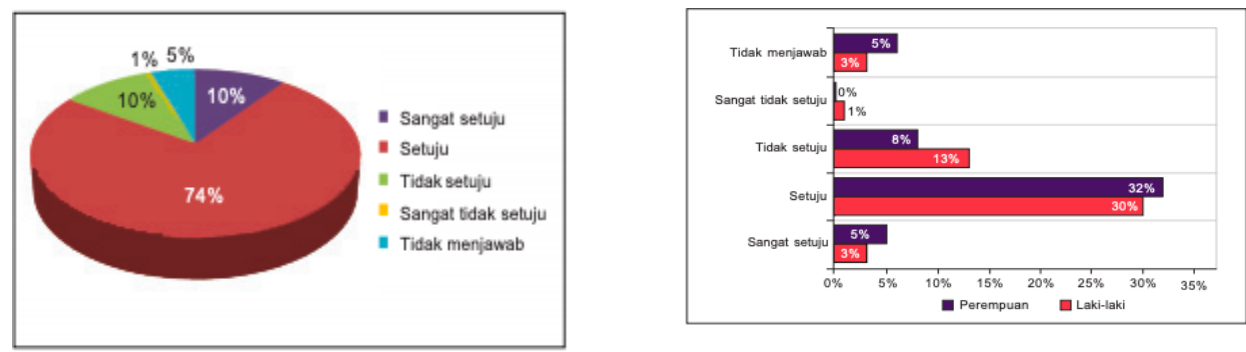

*Notes: Sangat Setuju: Very Agree; Setuju: Agree; Tidak Setuju: Disagree; Sangat Tidak Setuju: Very Disagree; Tidak Menjawab: Abstain; Perempuan: Women; Laki-Laki: Men Source: Women Research Institute Survey, 2014 
However, when talking about people's preference to vote male or female candidates by questioning who will be voted if they campaign in the same way and have the same capacity, people prefer to vote male candidate. Survey conducted by LSI and IFES in 2014 stated that around $55 \%$ respondent prefer to choose male candidate, while only $11 \%$ respondent will choose female candidate. The rest $32 \%$ of them said that there is no different preference in choosing either male or female candidate. While the $2 \%$ of them prefer not to answer (Ihsannudin, 2014). That type of voting preferences of voter is still remaining nowadays. LSI et.all survey in 2019 showed that 47, 7\% respondent disagree when the number of female leaders is increased (LSI, 2019). People still prefer male leader rather than female leader.

Looking at the data above, we can conclude that politics is still a big deal for women. Even though people agree to give the same opportunities to women and men in politics, they still assume that men is more preferable to be voted. However, by the advancement of technology that used by women as one of their platforms in campaigning herself, women find her way to get closer to the people. Based on simple surveys in this study, 68\% of 100 respondents stated that social media helps voters recognize and know the female candidates. What are constructed by the female candidates on their digital campaign through the construction of the political issues, candidate excellences, and candidate novelties through the publication of vision and mission programs, have been able to encourage public political literacy to become rational voters when seeing the female candidates. Social Media campaign at least can be a tool for women to reduce bias the society through its feature to blow up their programs in a borderless society.

Unfortunately, looking at the results of the 2018 regional election, the study concluded that there was no correlation between political marketing carried out by a female candidate and their winning. Of the five female candidates whom I observed, only Khofifah Indar Parawangsa, East Java governor candidate and Chusnunia, Candidate for Deputy Governor of Lampung, were elected as governors and deputy governors. Even if viewed from the number of political publications by both of them, these two candidates are not candidates with a high frequency of digital campaigns (see figure 4).

This finding shows a different result from previous research findings which stated that the more often candidates make digital campaigns, the greater chance they will get to be elected. This difference in findings can be caused by, among other things, digital media has not become the main media campaign by candidates in almost all regions of Indonesia. In addition, the disparity of internet penetration in Indonesia region and the need to increase people literacy are also the reason why this study results different output from the previous studies. Moreover, if it is associated with the study of women's winning factor in election, there are variety factors that can influence the electability of a female candidate. Factors such as social capital, networks, political kinship, and financial capital are still the dominant factors in women's candidacy (Sweinstani, 2018; Dewi \& Kusumaningtyas, 2018), especially when the status of women in politics is still considered a new actor in politics. However, at least digital campaigns can be media that help the construction of public perception to women in election to be less bias. 


\section{Conclusion}

The use of digital media as one of the methods of political marketing of female candidates for regional head has a positive impact on public perceptions of female regional head candidates. Although judging that politics is still a challenging domain for women, digital political marketing makes people know female candidates easier as well as make the female candidates find the easy to get closer to the people. Furthermore, campaigns that highlight the positive side of female candidates have been able to encourage public political literacy and make voters try to be rational voters against female candidates by evaluating based on the programs carried out.

With regard to the digital political marketing of female candidates, female candidates for regional head use digital campaign media as a means of building an image of political professionalism by placing more emphasis on uploading the vision and mission of the program carried out. Female candidates also have different ways in communicating with voters compared to male candidates. Women used various symbols of women's identity that are shown both in attracting the attention of voters and in campaigning for programs related to women's issues. In campaigning for "women's programs" female candidates try to show the illusion that they are parties who can better articulate the interests of women. The different used of women identity here is different with Hayes and Lawless finding as the fact that women are still categorized as the new actors in Indonesian politics. So that with the advantages of massive and broad social media, showing identity as an alternative leader in a region with a female identity can be one of their strategies in approaching voters.

Unfortunately, even though digital campaign seems make female candidates easier to get closer to the voters, it cannot be automatically concluded as contributing to the electability of female candidates. The use of this media is only a supporting system that can help them to get closer to the voters and construct people's perceptions of female candidates. This finding is different from the findings of the study of digital media in other advanced democracies countries that mostly conclude that there is positive correlation between digital campaign and candidate's electability.

Theoretically, this study succeeded in providing specific theoretical implications for elaborating the theory of Newman and Perloff. In this study, it was found that female candidates for regional heads did not try to direct their campaigns to certain voter markets, including specifically to women. This is because the electoral system used in regional head elections is FPTP which forces candidates to master all voters to win the election. In addition, the absence of segmentation of the target of political marketing is also due to the broader reach of social media than conventional political marketing media. This finding is an important finding for the authors because the authors found new indicators to elaborate on the Social Imaginary domain according to Newman and Perloff's political marketing theory. The indicator in question is the type of electoral system. If the electoral system used is an electoral system with a large number of districts (multi-member districts), the candidate will build the same social picture as the target audience. But if the electoral system is a single district that requires the candidate to get the most to win the election (winner takes all), then imaginary social tends to be abandoned because candidates try to gather votes from all elements of society. In addition, Newman and Perloff also have not been able to see this domain in the context of the development of communication technology that makes society become borderless. In the condition of this borderless society seen from digital media, the imaginary social domain constructed by Newman and Perloff became no longer relevant. 


\section{SOCIAL SCIENCES IN THE 21ST CENTURY}

\section{References}

Adam, S., \& Maier, M. (2010). Personalization of politics: A critical review and agenda for research. In C. S. (Ed), Communication Yearbook 34 (pp. 213-257). London: Routledge.

Andiana, N. (2013). Media Siber Sebagai Alternative Jembatan Komunikasi Antara Rakyat dan Pemimpinnya. Jurnal Penelitian Politik Vol. 10 No. 2 Desember 2013, 79-93.

APJII. (2017). Infografis Penetrasi dan Perilaku Pengguna Internet Indonesia. Survei 2017. Jakarta: APJII.

Attunes, R. (2010). Theoretical Models of Voting Behavior. Exedra No.4, 145-170.

Dewi, K. H. (2015). Indonesian Women and Local Politics: Islam, gender, and network in postSoeharto Indonesia. Singapore \& Kyoto: NUS Press \& Kyoto University Press.

Dewi, K. H., \& Kusumaningtyas, A. N. (2018). Refleksi Modal, Strategi, dan Jaringan Perempuan Politisi dalam Kandidadi Pilkada Langsung 2015: Sebuah Komparasi. In K. H. Dewi, Modal, Strategi, dan Jaringan Perempuan Politisi dalam Kandidasi Pilkada Langsung (pp. 167-190). Jakarta: Yayasan Obor.

Gibson, R. K., \& McAllister, I. (2006). Does cyber-campaigning win votes? Online communication in the 2004 Australian election. Journal of Elections, Public Opinion and Parties, 16(3), 243-263.

Hayes, D., \& Lawless, J. L. (2016). Women on the run: Gender, media, and political campaigns in a polarized era. Women on the Run: Gender, Media, and Political Campaigns in a Polarized Era. https://doi.org/10.1017/CBO9781316336007

Hootsuite; We Are Social. (2018). Digital in 2018 in Southeast Asia. Part 2: South-east. London: Hootsuite; We Are Social.

Ihsannudin. (2014). Survei: Perempuan Masih Dipandang Sebelah Mata di Dunia Politik Indonesia. $\quad$ Retrieved May 17, 2019, from https://nasional.kompas.com/read/2014/02/11/2159058/Survei.Perempuan.Masih.Dipan dang.Sebelah.Mata.di.Dunia.Politik.Indonesia

KPU RI. (2018). Laporan Pasangan Calon Tahap Penetapan. Retrieved May 7, 2018, from Info Pemilu: https://infopemilu.kpu.go.id/pilkada2018/paslon/tahapPenetapan

Krippendorff, K. (2004). Content Analysis: An Introductions to its Methodology (Second Edition). California: Sage Publication.

Mosse, J. C. (1993). Half the World, Half A Change. An Introduction to Gender and Development. Oxford: Oxfam.

Newman, B. I. (1999). Handbook of political marketing. Thousand Oaks, CA: Sage.

Newman, B. I., \& Perloff, R. M. (2004). Political Marketing: Teory, Research, and Aplication. In L. L. Kaid, Handbook of Political Communication Research (pp. 17-43). New Jersey: Lawrence Earlbaum Associates Inc.

Partini. (2014). Partisipasi Politik Perempuan dalam Praktik Kewarganegaraan. Jurnal Perempuan Vol 19 No. 2, Mei 2014, 41.

Reynolds, A., Reilly, B., \& Ellis, A. (2008). Electoral System Design. Stockholm: International IDEA.

Sanne, K. (2014). How Political Candidates Use Twitter and The Impact on Votes. Computers in Human Behaviour 34 (2014), 131-139.

Schwindt-Bayer, L. A. (2005). The incumbency disadvantage and women's election to legislative office. Electoral Studies, 24(2), 227-244. https://doi.org/10.1016/j.electstud.2004.05.001 


\section{SOCIAL SCIENCES IN THE 21ST CENTURY}

Situmorang, J. R. (2012). Pemanfaatan Internt Sebagai New Media dalam Bidang Politik, Bisnis, Pendidikan, dan Sosial Budaya. Jurnal Administrasi Bisnis (2012), Vol. 8 No. 1, 73-87.

Svaleryd, H. (2009). Women's representation and public spending. European Journal of Political Economy, 25(2), 186-198. https://doi.org/10.1016/j.ejpoleco.2008.12.004

Sweinstani, M. K. (2018, April 17). Hambatan Perempuan Calon Kepala Daerah dari masa ke masa; Masalah Struktutral atau Kultural. Dipetik May 7, 2018, dari Pusat Penelitian Politik-LIPI: http://politik.lipi.go.id/kolom/kolom-2/politik-nasional/1209-hambatanperempuan-calon-kepala-daerah-dari-masa-ke-masa-masalah-struktural-atau-kultur

Sweinstani, M. K. (2018). Money Factor in the Nomination of Chinese-Indonesian Women Legislative. 5th Bangkok International Conference on Social Science \& Humanities (ICSSH) (p. 51). Bangkok: GAHSSR Publisher.

Sweinstani, M. K., \& Mariyah, C. (2017). Political Recruitment Of Chinese-Indonesian Women Candidate: Study On PDI Perjuangan Recruitment In Nominating ChineseIndonesian Woman Candidate In Semarang City Legislative Election 2014. PEOPLE: International Journal of Social Science, 1156-1174.

Swers, M. L. (2002). The Difference Women Make: The Policy Impact Of Women In Congress. Chicago: Universiry of Chicago Press.

Warnick, B., Xenos, M., Endres, D., \& Gastil, J. (2005). Effects of campaign-to-user and textbased interactivity in political candidate campaign web sites. Journal of ComputerMediated Communication, 10(3).

Women Research Institute. (2014). Partisipasi Politik Perempuan Sebuah Keharusan. Jakarta. Retrieved from https://www.wri.or.id/files/Factsheet_Partisipasi_Politik_PerempuanJan_2014_Indonesia.pdf

Women Research Institute. (n.d). Wajah Muram Keterwakilan dalam Pilkada di Indonesia. Jakarta: WRI 